\title{
Impacts of intensive urbanization on trees in Hong Kong
}

\author{
CHI YUNG JIM* \\ D epartment of $\mathrm{G}$ eography and $\mathrm{G}$ eology, U niversity of $\mathrm{H}$ ong $\mathrm{K}$ ong, P okfulam R oad, H ong K ong \\ D ate submitted: 18 A ugust 1997 D ate accepted: 6 M arch 1998
}

\section{Summary}

Trees in cities face a severe limitation of plantable space and an exceptionally stressful growing environment. In Hong Kong, shortage of developableland has relegated trees to a lower priority and intensified urban impacts on them, relativeto other cities. Thevicissitudes of urban growth and trees since the founding of Hong Kong are reviewed, and eleven specific conflicts between urbanization and trees in Hong Kong are described. Redevelopment of existing buildings has raised site coverage by impervious surface and taken away ground-level planting space within and around affected lots. Infilling of relatively low-density areas mainly for government and institutional land-uses has increased development density and removed existing greenery and planting spaces. Road construction and improvement has widely damaged roadside trees and removed valuable and conspicuous greenery. Proliferation of underground utilities has fueled the contest for usable space and precluded planting in many places. Widespread and frequent roadside trenching, associated with utilities and the laying of cabletelevision and telecommunica tion networks has incurred massive root damage at roadsickes. Poor soil quality commonly beset by chemical and physical constraints has caused chronic poor tree performance Intrusion into urban parks and other green enclaves by buildings and roads has usurped the limited stock of green spaces. Encroachment into peri-urban woodlands has deprived the city of fringing mature greenery with conservation, landscapeand amenity worth. Plantable space in reclaimed lands has been intensively used with inadequate allocation for trees. Protection and preservation of champion specimens has lacked staturtory means and a coordinated policy. Reinforcement and demolition of stone walls has destroyed many large trees on unique mural habitats. Quality of arboricultural practice is poor, particularly in the private sector. Possible solutions to these limitations in Hong Kong are suggested, and haveimplications for other cities facing similar problems.

K eywords: urban trees, urban forestry, urban ecology, tree management, tree preservation

\footnotetext{
* Correspondence: Professor Chi Yung Jim T el: +852 28597020

F ax: +852 25598994 e-mail: hragjcy@ hkucc.hku.hk
}

\section{Introduction and historical backdrop}

The phrase 'urban tree' is apparently a contradiction in terms. 'U rban' connotes artificiality and trying conditions for life, yet 'tree' conjures up an image of nature and serenity which is commonly wanting in the city milieu. $T$ rees and cities, nevertheless, have coexisted for many years. It has been a customary practice in different cultures to plant trees as companions of settlements. The art and science of urban planting flourished in the seventeenth century in some European cities (Schmid 1975; L awrence 1988). T he urban greening practice was subsequently disseminated with the migration of Europeans and their cultural influence to different corners of the world. With more of the world's population living in cities, the environmental quality of urban centres will to a large extent determine the well-being of many people. Trees in cities can play a pivotal role in ameliorating the harshness of urban living, and their multiple functions and benefits have been extensively reviewed (e.g. Schmid 1975; Grey \& D eneke 1986; M iller 1988). U rban tree management, as an integral component of urban environmental management, is increasingly a concern of municipal authorities world-

Table 1 Some indicators of high-intensity urban development in $\mathrm{H}$ ong $\mathrm{K}$ ong (D ata sources: compiled from various $\mathrm{H}$ ong $\mathrm{K}$ ong G overnment statistics)

\begin{tabular}{|c|c|}
\hline Attribute & State \\
\hline \multicolumn{2}{|l|}{ L and area } \\
\hline total & $1095 \mathrm{~km}^{2}$ \\
\hline$>100$ m elevation ( $\%$ total) & approx. $870 \mathrm{~km}^{2}(79.5 \%)$ \\
\hline reclaimed (\% total) & $60 \mathrm{~km}^{2}(5.5 \%)$ \\
\hline developed (\% total) & $175 \mathrm{~km}^{2}(16.0 \%)$ \\
\hline \multicolumn{2}{|l|}{ Population } \\
\hline total & 6.5 million persons \\
\hline average density & 5938 persons/ km² \\
\hline average urban density & 26611 persons/ km² \\
\hline maximum urban district density & 53610 persons/ km² \\
\hline maximum urban spot density & 116531 persons/ km² \\
\hline \multicolumn{2}{|l|}{ Road length } \\
\hline total & $1717 \mathrm{~km}$ \\
\hline per unit area & $1.57 \mathrm{~km} / \mathrm{km}^{2}$ \\
\hline per person & $0.26 \mathrm{~km} / 1000$ persons \\
\hline \multicolumn{2}{|l|}{ V ehicle } \\
\hline total & 466068 nos. \\
\hline per unit road length & $271.4 / \mathrm{km}$ \\
\hline per person & 71.1/ 1000 persons \\
\hline \multicolumn{2}{|l|}{0 pen-green space } \\
\hline urban formal (\% total) & $16 \mathrm{~km}^{2}(1.5 \%)$ \\
\hline country park (\% total) & $413.5 \mathrm{~km}^{2}(37.8 \%)$ \\
\hline
\end{tabular}




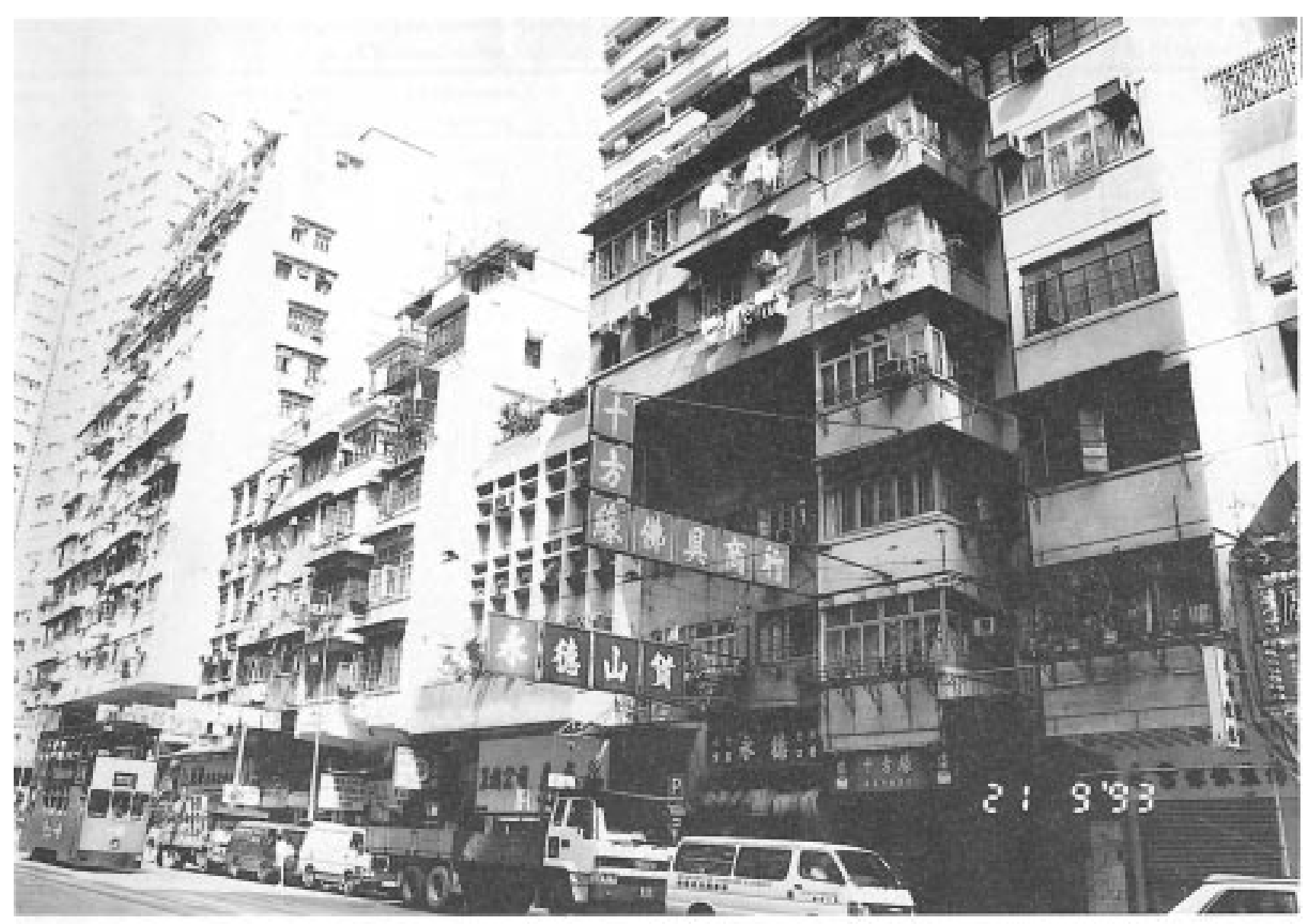

Figure $1 \mathrm{U}$ rban areas in $\mathrm{H}$ ong $\mathrm{K}$ ong are characterized by a maximum use of developable land, often with $100 \%$ impervious site coverage and absence of setback at road frontage, thus precluding the planting of intra- and peri-site trees.

wide in a quest to make it cost-effective. There is a common desire to reduce the pressure on urban trees and provide them with a better tenure.

$\mathrm{H}$ ong $\mathrm{K}$ ong, a city on the subtropical coast of China founded some 150 years ago, has served well as a synergistic confluence of eastern and western civilizations. Ideas from distant lands were earnestly adopted, including the insertion of amenity trees in the then $V$ ictorian township. $T$ ree species from various tropical lands were introduced through formal and informal channels ( Jim 1991, 1992a), and historical photographs (Warner 1979; H ong K ong M useum of History 1982) attest to the assimilation of this fine tradition. D espite the shortage of space for the growth of the city since $\mathrm{H}$ ong $K$ ong's inception, the pressure for land development did not preclude trees (J im 1992b), and every effort was made to permit their coexistence with artificial structures.

T he halcyon days for amenity vegetation have gradually succumbed to the relentless pressure to accommodate the rapidly-increasing population. Wars and turmoil in China pushed refugees into $\mathrm{H}$ ong $\mathrm{K}$ ong in droves, raising the population from a little less than one million before the Second World W ar to 3.13 million in 1961 (L o 1992) and 6.5 million in 1998. T he great expansion in human numbers necessitated land-use intensification, relegating the less exigent greening need to a low priority. The rapid urbanization fuelled consumption of land which is increasingly at a premium. Population density was raised to a level which is the world's highest, with an urban average of 26611 person/ $\mathrm{km}^{2}$ and a maximum 116531 person $/ \mathrm{km}^{2}$ (Census and Statistics D epartment 1997a).

Problems associated with urban-tree planting and management in $\mathrm{H}$ ong $\mathrm{K}$ ong are in many ways similar to those encountered in other cities (Bernatzky 1978; Gilbertson \& Bradshaw 1985; Bradshaw et al. 1995). The difference between $\mathrm{H}$ ong $\mathrm{K}$ ong and other cities is more in degree than in kind. $\mathrm{T}$ he vicissitudes of trees in urban $\mathrm{H}$ ong $\mathrm{K}$ ong reflect the universal phenomenon of intensive conflicts between artificial and natural components in cities, the associated landscape planning and management problems, and the possible solutions. H owever, the magnitude and pervasiveness of these problems due to the exceptional development density are much greater in $\mathrm{H}$ ong $\mathrm{K}$ ong. A main feature of this development intensity is the spatially-prevalent high-density and high-rise mode of development, extending all the way from the city centre to its peripheries ( $T$ able 1 ). T here is a lack of gradational reduction in density along a centre-to- 
Table2 $\mathrm{F}$ requency of 47 common tree species at roadside habitats in $\mathrm{H}$ ong $\mathrm{K}$ ong (\# denotes native species) ( $\mathrm{D}$ ata source: author's own census conducted in 1995 of the entire population of 19154 roadside trees in the main urban areas of $\mathrm{H}$ ong K ong)

\begin{tabular}{|c|c|c|c|c|c|c|}
\hline Rank & Species & Frequency & Per cent & $\begin{array}{c}\text { C umulative } \\
\text { per cent }\end{array}$ & $\begin{array}{c}\text { Final height } \\
\text { (m) }\end{array}$ & $\begin{array}{l}\text { Final crown } \\
\text { spread (m) }\end{array}$ \\
\hline 1 & A leurites moluccana & 2474 & 12.92 & 12.92 & $>15$ & \\
\hline 2 & M elaleuca quinquenervia & 1444 & 7.54 & 20.46 & $>15$ & \\
\hline 3 & P hoenix roebelenii & 1337 & 6.98 & 27.44 & $<5$ & \\
\hline 4 & L ivistona chinensis & 1325 & 6.92 & 34.36 & $10-15$ & \\
\hline 5 & Caryota ochlandra & 1018 & 5.31 & 39.67 & $>15$ & \\
\hline 6 & A rchontophoenix alexandrae & 688 & 3.59 & 43.26 & $10-15$ & \\
\hline 7 & \#B ombax malabaricum & 648 & 3.38 & 46.65 & $>15$ & \\
\hline 8 & Delonix regia & 647 & 3.38 & 50.02 & $>15$ & $>15$ \\
\hline 9 & Cassia siamea & 573 & 2.99 & 53.02 & $>15$ & $>15$ \\
\hline 10 & Cassia surattensis & 520 & 2.71 & 55.73 & $<5$ & \\
\hline 11 & \#F icus microcarpa & 476 & 2.49 & 58.22 & $>15$ & $>15$ \\
\hline 12 & W ashingtonia robusta & 473 & 2.47 & 60.69 & $10-15$ & \\
\hline 13 & Ficus benjamina & 445 & 2.32 & 63.01 & $>15$ & $>15$ \\
\hline 14 & \#H ibiscus tiliaceus & 437 & 2.28 & 65.29 & $5-10$ & \\
\hline 15 & Crateva religiosa & 429 & 2.24 & 67.53 & $>15$ & \\
\hline 16 & Thevetia peruviana & 421 & 2.20 & 69.73 & $<5$ & \\
\hline 17 & A cacia confusa & 415 & 2.17 & 71.89 & $5-10$ & \\
\hline 18 & \#B auhinia blakeana & 382 & 1.99 & 73.89 & $5-10$ & \\
\hline 19 & R oystonea regia & 363 & 1.90 & 75.78 & $>15$ & \\
\hline 20 & \#A lbizia lebbeck & 312 & 1.63 & 77.41 & $>15$ & $>15$ \\
\hline 21 & Casuarina equisetifolia & 272 & 1.42 & 78.83 & $>15$ & $>15$ \\
\hline 22 & Peltophorum pterocarpum & 265 & 1.38 & 80.22 & $10-15$ & \\
\hline 23 & S pathodea campanulata & 236 & 1.23 & 81.45 & $10-15$ & $>15$ \\
\hline 24 & Cycas revoluta & 195 & 1.02 & 82.47 & $<5$ & \\
\hline 25 & G revillea robusta & 146 & 0.76 & 83.23 & $10-15$ & \\
\hline 26 & \#A ilanthus fordii & 144 & 0.75 & 83.98 & $5-10$ & \\
\hline 27 & Eucalyptus citriodora & 141 & 0.74 & 84.72 & $>15$ & \\
\hline 28 & E ucalyptus robusta & 139 & 0.73 & 85.44 & $10-15$ & \\
\hline 29 & \#C eltis sinensis & 133 & 0.69 & 86.14 & $>15$ & $>15$ \\
\hline 30 & Jniperus chinensis & 131 & 0.68 & 86.82 & $<5$ & \\
\hline 31 & \#B ischofia javanica & 122 & 0.64 & 87.46 & $10-15$ & \\
\hline 32 & \#M acaranga tanarius & 120 & 0.63 & 88.08 & $5-10$ & \\
\hline 33 & \#C innamomum camphora & 114 & 0.60 & 88.68 & $>15$ & $>15$ \\
\hline 34 & Tristania conferta & 109 & 0.57 & 89.25 & $10-15$ & \\
\hline 35 & Syzygium jambos & 98 & 0.51 & 89.76 & $5-10$ & \\
\hline 36 & \#Cinnamomum burmanii & 91 & 0.48 & 90.24 & $<5$ & \\
\hline 37 & Syagrus romanz offiana & 88 & 0.46 & 90.69 & $5-10$ & \\
\hline 38 & \#Schefflera octophylla & 79 & 0.41 & 91.11 & $<5$ & \\
\hline 39 & \#F icus virens & 78 & 0.41 & 91.51 & $>15$ & $>15$ \\
\hline 40 & M ichelia alba & 77 & 0.40 & 91.92 & $>15$ & $>15$ \\
\hline 41 & L agerstroemia speciosa & 76 & 0.40 & 92.31 & $5-10$ & \\
\hline 42 & Pterocarpus indicus & 70 & 0.37 & 92.68 & $>15$ & $>15$ \\
\hline 43 & A raucaria heterophylla & 62 & 0.32 & 93.00 & $10-15$ & \\
\hline 44 & $\mathrm{~K}$ haya senegalensis & 62 & 0.32 & 93.33 & $>15$ & $>15$ \\
\hline 45 & M elia az edarach & 61 & 0.32 & 93.64 & $10-15$ & \\
\hline 46 & Bauhinia variegata & 57 & 0.30 & 93.94 & $5-10$ & \\
\hline \multirow[t]{2}{*}{47} & E rythrina variegata & 51 & 0.27 & 94.21 & $5-10$ & \\
\hline & Total & 18044 & 94.22 & & & \\
\hline
\end{tabular}

edge gradient that is common in many cities. M ost urban lots have been used to their maximum potential, often with $100 \%$ impervious site coverage at the ground level with no setback from the frontage and no within-lot openings. The intervening roads often have inadequate space for roadside amenity planting (Fig. 1). Whereas new trees are being planted, the old ones face tremendous pressure and degeneration (Olembo \& de Rham 1987). T he so-called inner-city type of environment is therefore found in the bulk of the metropolis, cramped into a small $1095 \mathrm{~km}^{2}$ of land of which about three- 


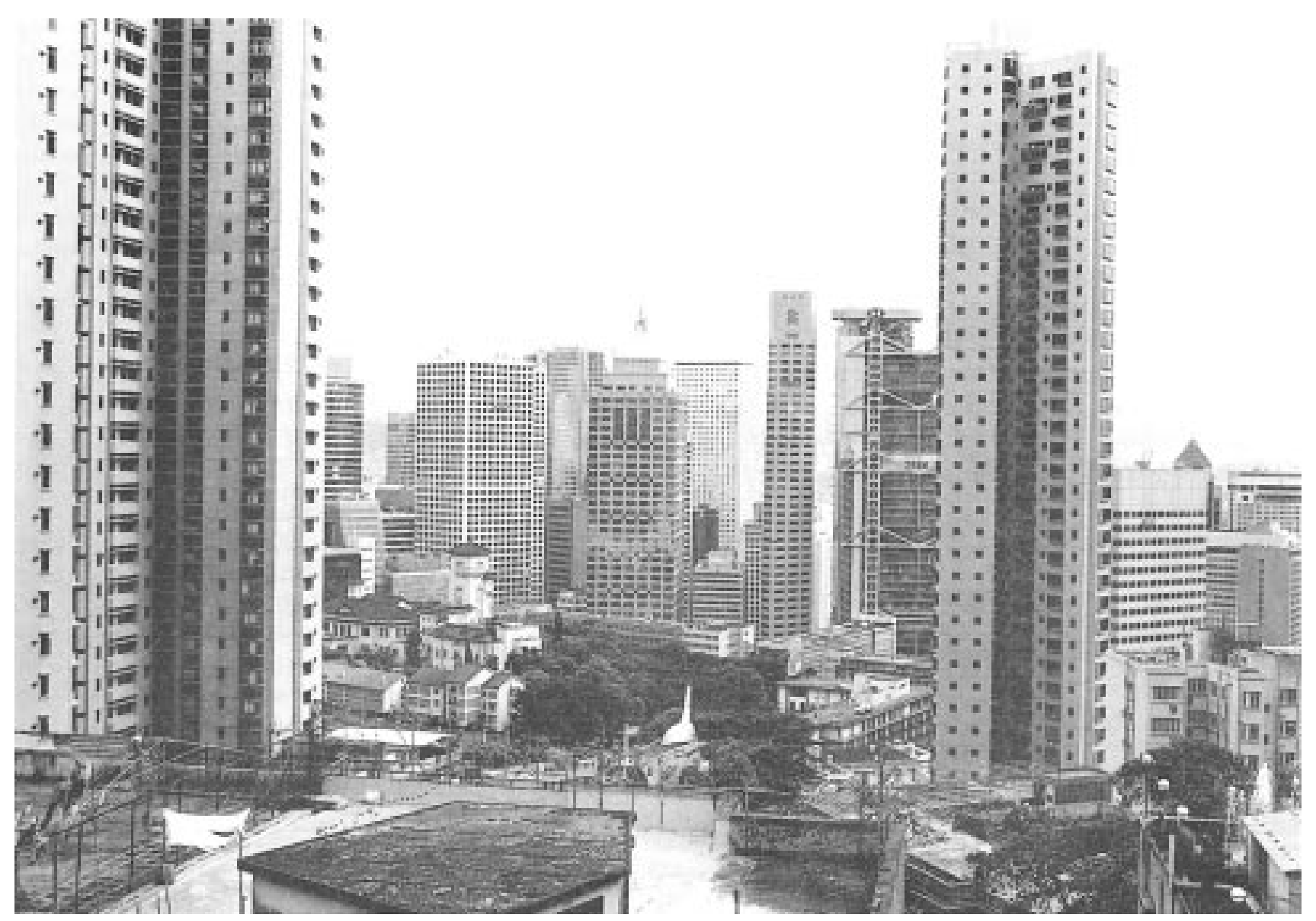

Figure $2 \mathrm{~T}$ he high-rise and high-density urban fabric in H ong $\mathrm{K}$ ong is occasionally punctuated by low-density and low-rise government, institutional and community (GIC) plots which allow tree existence. Redevelopment of such sites often results in the loss of valuable greenery spaces.

quarters are not easily developable due to difficult terrain. $\mathrm{H}$ ong $\mathrm{K}$ ong is a phenomenal congregation of buildings and roads with little intervening open spaces. Amenity trees are meagre and exist in confined growth space ( $T$ able 2). Opportunity for greenery is inherently and severely constrained ( Jim 1987a).

By comprehensively assessing the varied and intensive pressures of urbanization on trees in $\mathrm{H}$ ong $\mathrm{K}$ ong through an analysis of tree-dampening factors and processes at the macro- and micro-scales, this study aimed to determine how urban tree-care might be improved so that long-term improvement in the quantity and quality of city greenery might be effected.

\section{Reckevelopment of existing buildings}

Due to inadequacies in building design, construction method, material and maintenance, vis-à-vis the aggressive humid-tropical weather, most buildings in $\mathrm{H}$ ong $\mathrm{K}$ ong tend to deteriorate substantially within a matter of several decades (Bristow 1984). T he cycle of urban renewal here is thus exceptionally short in comparison with temperate cities.
The transient state of the city's structures should provide many opportunities to revamp the town plan, but redevelopment at a much higher intensity ( $\mathrm{Jim} \mathrm{1994d)}$ is more often than not the case in many urban-renewal schemes due to an ever-increasing demand for building space and world-record real-estate values (W ong et al. 1996). M oreover, the renewal frequently occurs in a piecemeal and uncoordinated manner (Bristow 1984) and the opportunity to rectify past excesses and negligence in terms of urban landscaping and environmental quality is rarely taken.

In the course of redevelopment, within-lot trees are often removed completely, resulting in significant reduction in the urban tree cover in recent years ( J im 1989a, 1990a). Few trees are preserved in situ (J im 1988). T hesmall and cramped building lots, commonly sandwiched between adjacent buildings, do not leave much latitude for engineering manoeuvre. Where trees are occasionally kept, the ensuing demolition and subsequent construction activities often leavethem in adismal state. Roadside trees abutting lot boundaries usually cannot escape a similar ill fate. The common practice of building up to lot boundaries, and erecting awnings abovethenarrow pavement, do not augur well for peripheral roadside vegetation. 
The poor-quality tree-care on construction sites ( $\mathrm{Jim}$ 1987a) can be improved if contractors adhere to arboricultural standards (British Standards Institution 1991; NHBC 1992); for example, stressful site conditions can be improved by measures such as soil improvement and replacement (D udle 1986). High-calibre existing trees affected by construction should be carefully evaluated and preserved in situ by a sympathetic building plan, failing which, transplanting should be recommended. Statutory planning measures are needed to preserve growing space (Profous et al. 1988) and to institute a coordinated setback of buildings by zoning to supply more roadside amenity strips. A long-term greening strategy should aim at providing good-quality planting sites (K elcey 1978) to be disseminated throughout the city in a matrix enmeshing built-up areas.

\section{Infilling of relatively low-density sites}

Development of occasional low-density sites earmarked for government, institutional and community (GIC) uses, such as schools, churches, and hospitals, allows less impervious site coverage (e.g. $<50 \%)$ at the ground level; space not occupied by buildings is often filled with trees and other greenery (J im 1987b; N owak 1994). U rban morphology as a determinant of tree-cover structure (Sanders 1984) is strongly expressed. This is a deliberate configuration in the urban design of $\mathrm{H}$ ong $\mathrm{K}$ ong which breaks the otherwise close packing of tall buildings with relieving gaps; together with formal open spaces, such vegetation plays an essential role in environmental amelioration (Fig. 2).

U rban rejuvenation has recently begun to consume GIC sites which are well placed and have good transport linkages. A low-rise and low-density (such as schools or churches) urban morphology can give way to high-rise office or residential blocks, with permanent loss of ground-level open space and greenery. T he more massive new buildings generate more traffic, which in turn necessitates higher capacity roads and less roadside space for amenity planting, in a snowballing effect which reduces the green cover (Jim 1990a) and degrades the urban landscape.

T he population is highly polarized in terms of tree ownership; a few rich people can afford houses with gardens in core city areas, but the rest must do without or share a tiny pool of communal trees. This tree-ownership dichotomy deviates from the close socio-economic association between tree characteristics and income-group neighbourhood found in other cities (Schmid 1975; T alarchek 1990), and the gap is widening due to rising property prices and infilling.

Infilling contradicts the purported policy of reducing population density in the older neighbourhoods (Planning D epartment 1993) and defeats the important objective of improving quality of life. A high proportion of impervious surface cover in a city has been used as an indicator of poor environmental well-being and quality of life (Arnold \& $G$ ibbons 1996). T here is a need to guard against indiscriminate infilling through statutory zoning. Low-density sites playing an important role in diluting the negative environmental aspects of high-density areas should be identified by a comprehensive study and be designated as special areas for cityscape conservation. A clear official message should be sent to developers that infilling is detrimental to environmental quality and will not normally be approved. In new developments, the tradition of breaking densely-packed areas with more spacious and green GIC sites should continue, with due regard to spatial spreading of such benefits.

\section{Road construction and improvement}

Of the different habitats for urban trees, the roadside is the most inimical (Barlett T ree Expert Company 1968; Richards \& Stevens 1979; Chevallerie 1986), and this is particularly so in core urban $\mathrm{H}$ ong $\mathrm{K}$ ong ( $\mathrm{J}$ im 1997a, b; Figs. 3 \& 4) where inherently difficult site conditions are aggravated by frequent roadwork imposing severe damage and injury on existing trees. In hilly districts, the narrow and winding old roads largely follow the contour (T regear \& Berry 1959). Increasing development density necessitates upgrading to meet traffic needs and modern road design and safety standards. Widening and straightening, gradient adjustments, drainage installations and roadside cut slope stabilization are most destructive to roadside vegetation.

Recent disastrous slope failures have accentuated concern for the stability of roadside engineered slopes and therefore shotcrete (concrete diluted with water and pump-sprayed onto the bare soil surface reinforced with steel-wire mesh) has been extensively applied to seal unstable slopes. T he re sulting surfaces are sterile and roadside slopes scars are left instead of living green cover. T he stripping of sylvan roads has drastically degraded landscape quality, leaving roads barren and harsh.

In densely built-up parts of the city, frequent road improvement work, such as realignment and widening, requires adjusting the road-lot interface. $T$ his adjustment often re sults in removal of roadside trees. Specific types of harm include grade change, truncation or burial of soil and roots, injury and lopping of branches. Only rarely can trees be preserved, but this usually entails severe confinement in incongruous niches, such as shifting from roadside to median positions and entrapment in tiny island plots. T raffic-volume increase after road improvement raises air pollution loading, both gaseous and particulate, which exacerbates stresses to remnant trees.

Roadwork affecting trees should be preceded by a comprehensive tree survey identifying target specimens for preservation or transplanting ( Jim 1996a, b), and most importantly providing a basis to modify the alignment to minimize damages on greenery. $\mathrm{N}$ ew or refurbished roads should seize every opportunity to furnish roadside planting spaces (Evans et al. 1990; G oldstein et al. 1991). Rather than being treated as dispensable adjuncts, trees should be recognized as an integral component of a road. A change in the ingrained attitude of relevant professionals, to be encouraged 


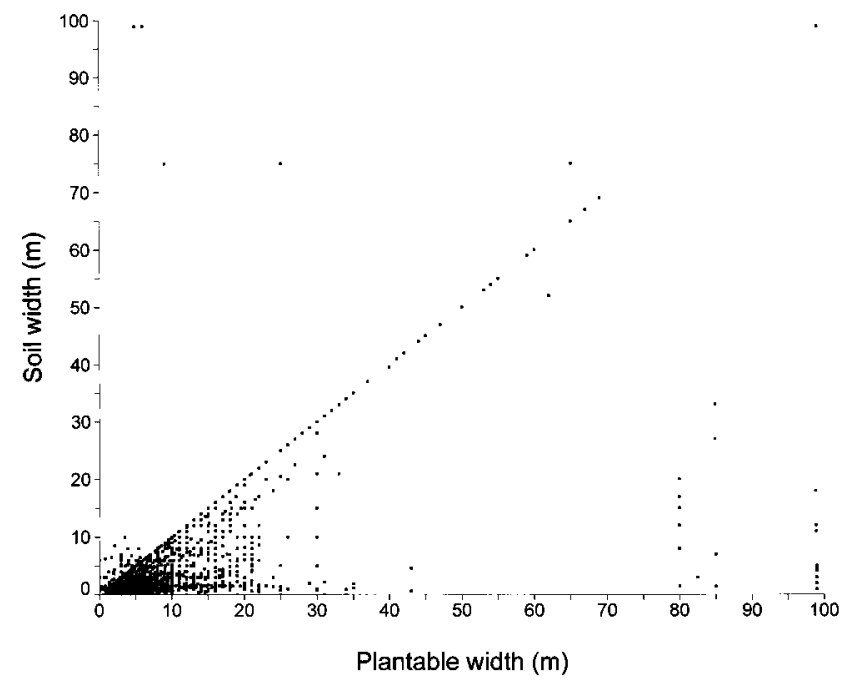

Figure 3 Plot of soil width (room for root expansion) against plantable width (room for crown expansion) for urban trees in H ong K ong ( $n=19154$ trees) (D ata source: author's own census conducted in 1995 of the entire population of roadside trees in the main urban areas of $\mathrm{H}$ ong $\mathrm{K}$ ong). by a forceful government policy, may bring relief in the long term.

\section{Proliferation of underground utilities}

All utility lines are buried underground in $\mathrm{H}$ ong $\mathrm{K}$ ong. $\mathrm{C}$ able television brings the latest onslaught, mainly routed through pavements, which has aroused alarm in other cities (Pearce 1994) and precludes many roadside sites from future planting. With limited roadside space, utilities are restricted to subterranean corridors, with extremely keen competition for usable space. T he unregulated disposition has usurped treerooting room under pavements and obstructed root growth.

To avoid conflicts, utilities are given priority and trees are eschewed, leaving many roads treeless. F ew roads are endowed with a dedicated tree strip free from the entanglements of buried utilities. Existing amenity corridors often cannot be kept due to conversion into additional carriageways to meet traffic requirements. Repeated excavations are needed to repair, overhaul, upgrade and cut utilities. Roots are massively severed, weakening trees and

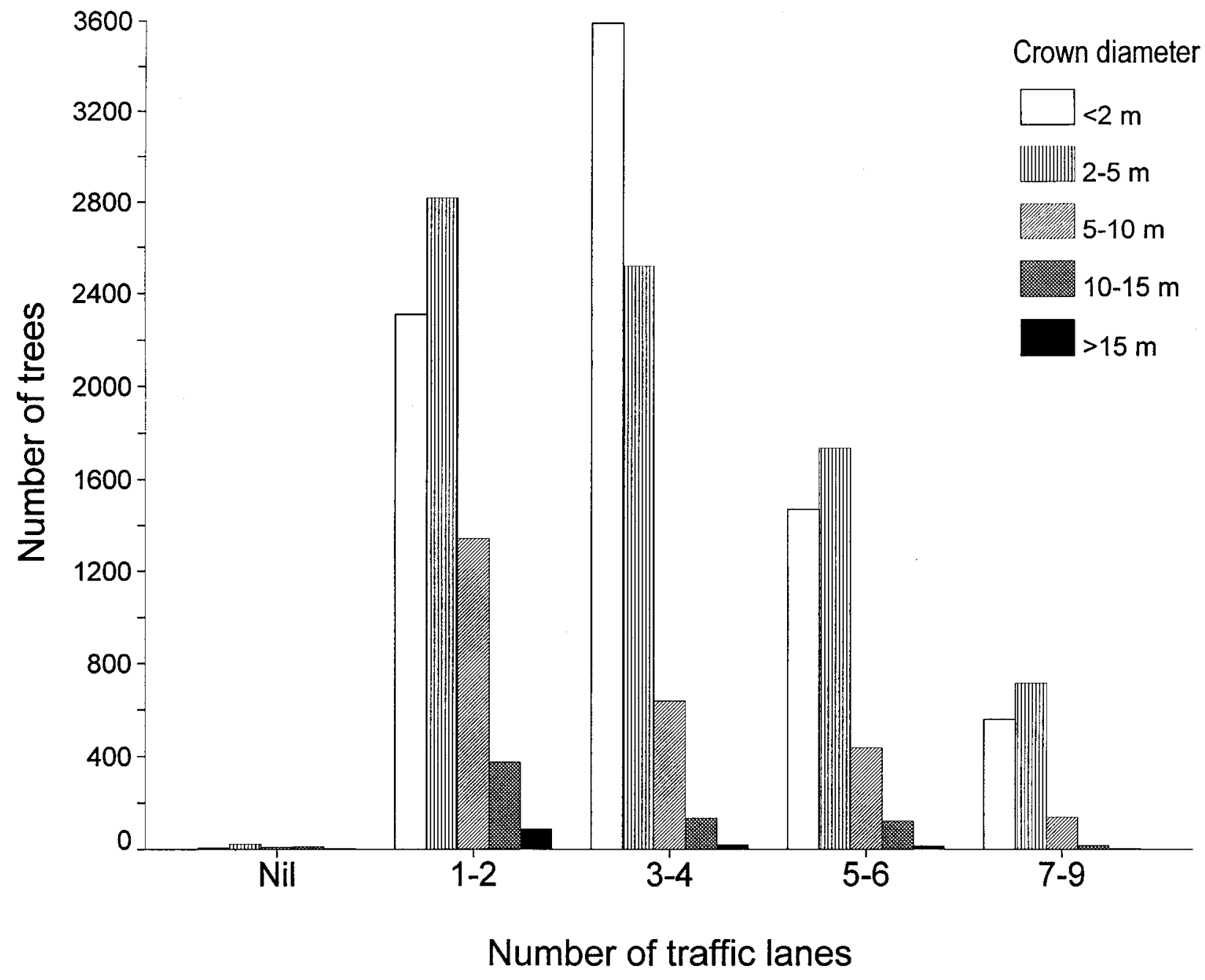

Figure $4 \mathrm{~F}$ requency of trees $(n=19154)$ in urban $\mathrm{H}$ ong K ong growing along roads with varying width (number of traffic lanes) ( $D$ ata source: author's own census conducted in 1995 of the entire population of roadside trees in the main urban areas of $\mathrm{H}$ ong $\mathrm{K}$ ong). 


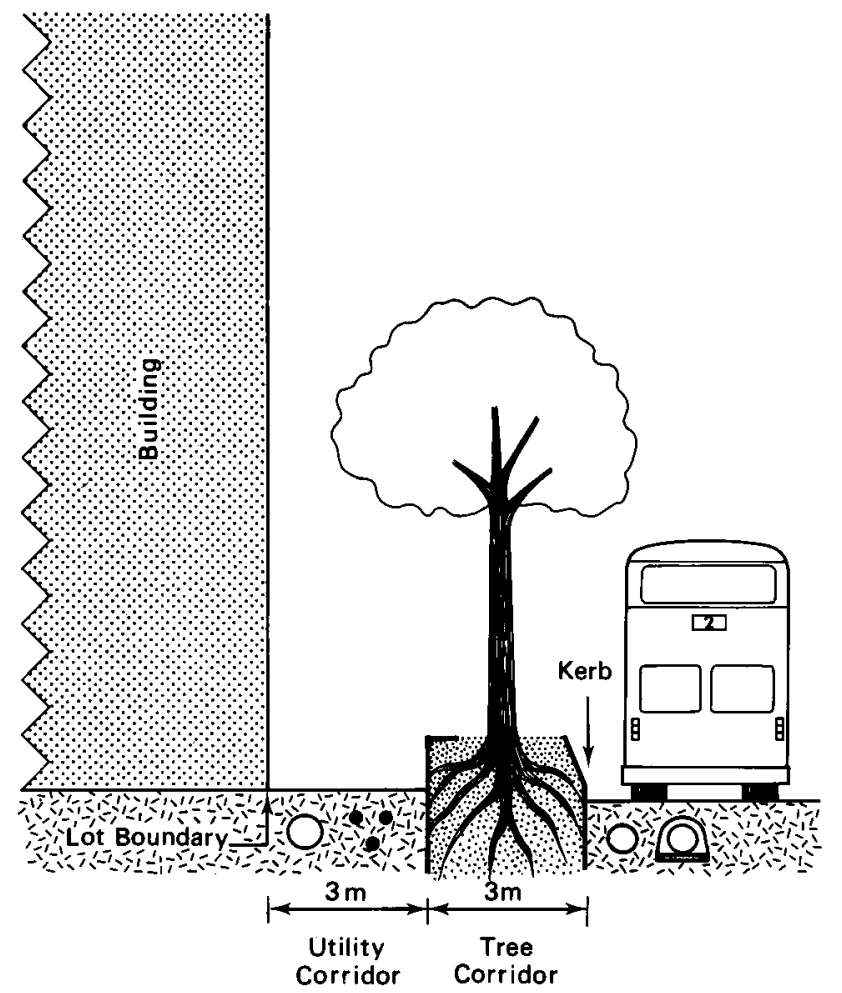

Figure 5 T o forestall the intense conflicts between underground utilities and tree roots, a clear separation of the tree corridor (to be filled with good-quality soil) from the utility corridor can be adopted in new development areas.

predestining them to a below-par performance and premature decline.

T hat unregimented buried services will bring havoc to roadside trees should be brought home to utility and construction companies (M orell 1992). Conflicting users require spatial separation within the subterranean space. T o secure rooting room, the tree-planting corridor should be protected by a permanent division from the utility corridor (Fig. 5). Improving communication between urban foresters and concerned industries can work towards a mutually-acceptable code of practice (National Joint U tilities Group 1995). A higher standard of material and workmanship should reduce the need for too frequent repairs.

\section{Widespread and frequent roadsidetrenching}

Repairing and laying utility lines, including the recent installation of territorywide networks for cable television and communication has demanded extensivetrenchingal ong pavements. T he widespread root injuries and severance, and the poor quality of workmanship with respect to treecaremay have triggered a long-term tree decline. Similar damage (Baines 1994; G ardening Which 1996) is happening in H ong K ong. F ull-scale excavation under the canopy of large trees is widely practised, as is digging next to the trunk base. Straight-line least-distance and least-effort routing is routinely practised.
There is little evidence of professional arboricultural guidance on how to minimize impacts of root cutting and shock on trees. The fact that most tree roots are concentrated in the top one metre or so of the soil (Perry 1982, 1994; Cutler et al. 1990; Gasson \& Cutler 1990), and that they spread out well beyond the area defined by the crown's dripline (Gilman 1988, 1989), have been ignored in road opening practices. $\mathrm{H}$ ardly any measure is taken to contain root injury and to protect exposed roots. T renching aggravates the common problem of confined rooting volume, and may introduce foreign materials into urban soils, disturb soil structure, compact the soil, and expose injured roots to pathogenic incursion. These deleterious impacts are the major cause of widespread poor performance of roadside trees.

Arboricultural standards associated with trenching near trees (N ational Joint U tilities Group 1995) should be followed by contractors, to be supported by penalties for poor practice. Recommendations are that: (1) qualified arboriculturists should be employed by utility companies to train the construction staff and monitor their work; (2) trenching should be diverted away from valuable specimen trees; and (3) minimum digging or non-digging technique, such as micro-tunnelling by mechanical or hydraulic drilling, should be adopted for high-calibre trees.

\section{Poor soil quality}

T he urban-tree programme in $\mathrm{H}$ ong $\mathrm{K}$ ong, similar to other cities, tends to focus on the above-ground space and subaerial portion of trees (Shigo 1989; Harris 1992). Actions on urban soils and tree roots are often indirect and minimal, such as adding amendments at the time of planting ( $\mathrm{H}$ arris et al. 1977; Chaney et al. 1992), correcting girdling roots which occur at the soil level (Shaw 1977; W atson et al. 1990), and repairing hard pavings cracked or heaved by roots (Barker 1994; K opinga 1994). Poor soil quality is a significant cause of depressed aesthetic and other environmental benefits of trees (G rey \& D eneke 1986; M iller 1988).

$M$ ost soil at roadside and offroad sites is drastically disturbed (Bullock \& Gregory 1991; Craul 1992; Watson \& $\mathrm{N}$ eely 1994), with loss of natural soil horizons and contamination by heterogeneous and haphazardly-deposited fill materials. U rban tree growth is dampened by soil constraints including rooting volume and physical and chemical composition. Occasional soil replacement (Watson et al. 1996) is limited to a small volume within a soil pit or a narrow channel.

U rban soils in $\mathrm{H}$ ong $\mathrm{K}$ ong show pervasive severe soil compaction (Jim 1993c), leading to low porosity, restricted aeration, sluggish infiltration and drainage, inadequate storage capacity for plant-available moisture (Whitlow et al. 1992), and physical obstruction to root growth. Chemical problems are equally common ( $\mathrm{Jim}$ 1998a, b), such as macroand micro-nutrient deficiencies, limited nutrient-holding capability, contamination by pollutants inherited from fill materials and alkalinity due to ubiquitous use of cement and 
concrete in the built environment (M essenger 1986; Ware 1990). Other less common but vexing problems include high soil temperature (H alverson \& H eisler 1981) and natural gas leakage from buried pipes (G ilman et al. 1982).

D espite these problems, site soils are accepted in bulk with little questioning about their suitability for plants. Existing work, mainly focusing on extrapolation of general soil science concepts to applications in urban forestry, should bereinforced by comprehensive empirical research in different urban habitats and climatic regimes. U rban soil science should be nurtured as a subdiscipline with a view to developing specific ameliorative measures for poor soil properties. Specific problems that need attention are compaction, restricted rooting volume, textural discontinuity, degraded structure, moisture deficit, alkaline reaction, low organic matter, low nutrient content and exchange capacity, and soil pollution. An urban-soil specification for landscape planting should be designed taking into account local soil conditions and availability of materials. A long-term soil management regime for different habitats should al so beadopted. It isnecessary to rectify thecurrent bias of caring for young plants within the establishment period whilst neglecting the long-term health of mature trees. This calls for nurturing a soil-management ethos amongst urban foresters and arboriculturists.

\section{Intrusion into urban parks and other green enclaves}

$\mathrm{H}$ ong $\mathrm{K}$ ong city is short of open spaces in comparison to the population base. Private gardens are rare except in the few high-income group neighbourhoods with single-family houses ( J im 1993b). T he main urban areas have a mere 4000 house-type residential units, accommodating $4 \%$ of the population (Census and Statistics D epartment 1997b). M ost residents live in high-rise flats, communal open-space provision is inadequate, resulting in very heavily patronized urban parks. D ue to transport needs, public parks and gardens are often intruded upon, with a steady loss of public open spaces and erosion of their amenity worth.

An alternative configuration increasingly being adopted recently is to lift green space up to rooftop, i.e. the podium level, and put roads and commercial uses underneath. This arrangement has been practised in private housing developments where the communal recreational facilities and gardens are usually placed on the top of a podium. The imminent extension of railways into the city requires the loss of several highly-popular parks and gardens to accommodate masstransit stations (KCR 1997). Open-space plots are often utilized as temporary storage or work areas for nearby construction projects, causing vegetation damages.

The city has several barracks which originally occupied fringe or rural lands when they were commissioned more than a century ago. In the last few decades, several intra-city barracks had been converted into urban parks to relieve openspace shortfall, and are endowed with many mature trees (Jim 1990e). Before land-use conversion, these green enclaves contrasted vividly with the surrounding heavily built-up areas, with rich green ingredients to serve as readymade urban parks. W ith central locations, however, parts of the former barracks had been earmarked for office and residential blocks. Such a legacy of historical accident will not be repeated in the future.

T he preservation of the limited total acreage of open green spaces in urban $\mathrm{H}$ ong $\mathrm{K}$ ong should receive wide support. Ready-made green spaces such as barracks should be converted into urban parks as a matter of official policy rather than as a response to vociferous public outcry. An eval uation of such suitable sites should be included in a city-wide landscape master plan. Where building incursion cannot be avoided, compensatory land provision should be made mandatory with full replacement of tree losses.

\section{Encroachment into peri-urban woodlands}

T wo modes of urban growth, namely reclamation from the sea and terracing hillslopes, are practised in $\mathrm{H}$ ong $\mathrm{K}$ ong ( $\mathrm{J} \mathrm{im}$ 1990a). W hereas reclamation generates new land initially devoid of plants, encroachment into the hills can bring havoc to existing woodlands of high amenity value. The steep cityfringe hillslopes are enveloped by a rather continuous stretch of mature woodlands, a product of decades of assiduous afforestation initiated in the late nineteenth century. U rbanization thus had the dualistic effect of increasing the tree cover at the city's edge, whilst reducing it within the city proper (Andresen 1978). In other cities, urbanization can decrease tree cover at the edge (e.g. cities in forests) and increase it in the city proper (e.g. cities in deserts). The periurban woodlands ( $\mathrm{im}$ 1989a) are valuable due to diversified composition and physiognomy, containing some of the largest mature trees in the territory. They are also ecologically important as the repository of some rare and unusual species of flora and fauna (T hrower 1975).

W oodlands in a spoke-like configuration extending into the developed areas are particularly valuable as green corridors. Such tongues of hillslope woodlands at the urban edge ( $\mathrm{J}$ im 1989a, b) provideadesirableinterpenetration of city and nature. $T$ hey denoteamuch higher-order of greenery that cannot possibly be replicated or emulated in the bland roadside or urban-park settings (T regay 1979). T he countryside fingers al so serveas easily-accessiblepassiverecreational outlets which can be reached within minutes from the city's heart. As such, they havehigh amenity aswell asconservation values. Such cityfringe woodlands, not uncommonly found in other big cities, are often subject to development threats ( $G$ oldsmith 1988).

Unfortunately, city expansion has intruded into periurban woodlands, particularly the green corridors, resulting in destruction of vegetation cover, wildlife, ecology, soil, landform, and landscape. Past hill-terracing operations mainly cleared small isolated enclaves, leaving intervening woodland strips occluded within the urban matrix. Recent hill terracing tends to clear large areas to create large building platforms, leaving huge and ugly scars of cut slopes. In new towns developed since the 1970s, some attempts have been 
made to preserve good-quality woodlands within their boundaries. They are, however, fragmented remnants of the original more continuous covers (Hill 1985). Some pockets have degenerated into woodland slums (H oltam 1980) due to continual damage and neglect.

Where urban intrusion cannot be avoided, impacts can be reduced by preserving pockets of original wooded hillslopes, to be sympathetically blended with future development (D orney et al. 1986). Such quasi-wilderness and wild enclaves (M anning 1979) are particularly precious near or better still within urbanized areas. M oreover, new intraurban and peri-urban woodlands can be created by appropriate site allocation, preparation and selection of species assemblage. Small pockets of remnant precinct woodlands (Izumi 1983) can be nurtured in the midst of high-density areas. Preferably, the vegetation cover should form a connected network enveloping built-up areas to maximize their benefits in the city environment (Henke \& Sukopp 1986). To protect against intrusions, they could be designated as green belts, or better still conservation areas, in statutory land-use zoning (Planning D epartment 1996).

\section{Plantable spacein reclaimed lands}

As much as $60 \mathrm{~km}^{2}$ of built-up areas around the harbour, about a quarter of the total urbanized areas, were reclaimed from the sea. The initially vacant land could have provided excellent opportunities for comprehensively green-space planning, with due regard to quantity and more importantly to quality and connectivity aspects. U nfortunately, the high cost of land production and the grave shortage of developable land have nurtured a policy of excessive development intensity especially in the 1960s and 1970s (T regear \& Berry 1959; Bristow 1984). With few site constraints, there was the temptation in the past to maximize building density.

$T$ he legacy of frenetic city growth in the last few decades is evidenced by large tracts completely filled by buildings and roads, devoid of greenery ( J im 1987b). T he older reclaimed lands have some isolated and dispersed amenity plots, mainly created recently by demolition of old buildings. The roadsides are too narrow for planting strips or tree pits (J im 1993a), with restrictive conditions for tree growth, and existing trees have to struggle to survive in poorly prepared sites.

Recently, a more enlightened attitude towards land-use and environmental quality has been adopted. T he new-town programme has since the 1970s transferred some two million people to the hitherto rural $\mathrm{N}$ ew T erritories. $\mathrm{M}$ ore open spaces have been designated (Bristow 1989) to allow a more heterogeneous urban form. W ith large-scale land reclamation planned and land to be released by the decommissioning of the existing intra-city airport, a green city within the old city can becreated. At themacrolevel, thechanceto implement the desirable green matrix concept (Scott et al. 1986) should not be missed. L inear roadside tree corridors could link nodes of larger green spaces such as gardens and parks, so as to maximize visual and environmental benefits. At the detailed level, proper sites should beearmarked for trees in the nascent urban land in terms of underground and above-ground growth dimensions, quality of the growth medium, and particularly good-quality soil with adequate drainage and aeration.

\section{Protection and preservation of champion specimens}

A tiny proportion of trees, despite inimical site conditions, have managed to attain the champion or elite rank (Randall \& Clepper 1977; M itchell et al. 1990) by a fortuitous combination of circumstances. M eritorious genetic make-up, dwelling in a genial environment with freedom from damages, injuries, pests, diseases and typhoon destruction, have permitted them to mature into outstanding specimens in terms of size, form, health and vigour. The main urban areas of $\mathrm{H}$ ong $\mathrm{K}$ ong, with some 25000 roadside and 35000 park trees, have merely 365 trees rated as champions (J im 1994a). $T$ he detailed information gleaned in a recent study has been published by the municipal council ( Jim 1994b) as an unofficial register of the most prominent sylvan members.

$W$ ith the current growth environments, it is difficult to nurture elite-grade trees. In fact, few trees planted in the postSecond W orld $W$ ar years manage to attain or have the hope of attaining outstanding quality ( $\mathrm{Jm} \mathrm{1994a).} \mathrm{The} \mathrm{inherited}$ champions are especially valuablein view of their relict nature, as a rarity that is being threatened and gradually eroded. They deserve a special protection status, preferably bestowed by statutory measures, which are not currently provided in $\mathrm{H}$ ong $\mathrm{K}$ ong. $\mathrm{T}$ he protection accorded by a tree protection clause included in some land-lease documents, and the Summary O ffence Ordinance is construed as ineffectual. Whereas such trees in government lands are given attention if they are threatened by public development, those in private lots need augmented legal protection (Coughlin et al. 1988).

There is a general lack of awareness and recognition that champion trees should bepreserved as the community's inheritance. They receive inadequate care and continue to be damaged even after the publication of the unofficial inventory ( Jim 1994b). T he car efree attitude of the community towards theexemplary trees should berevamped. I n particular, theprofessionals associated with developers should learn to respect them and takeconcreteaction to preservethecity'sdiminishing living heritage ( Jim 1995). To convey forcefully the relevant message, plaques could beerected near thetrees. A programme of inspection and care can be instituted to ensure timely and long-term attention. A legal instrument, analogous to a tree preservation order, as adopted in other countries (Batho 1990; Profous \& L oeb 1990) should beenacted.

\section{Reinforcement and demolition of stonewalls}

$M$ any cities have patches of remnant nature or unique habitats, harbouring special assemblages of biota and deserving protection from intrusions ( J ohnston 1990). H ong K ong has a large urban portion built on hillslope terraces created by expensive engineering endeavours. In the past, the traditional 


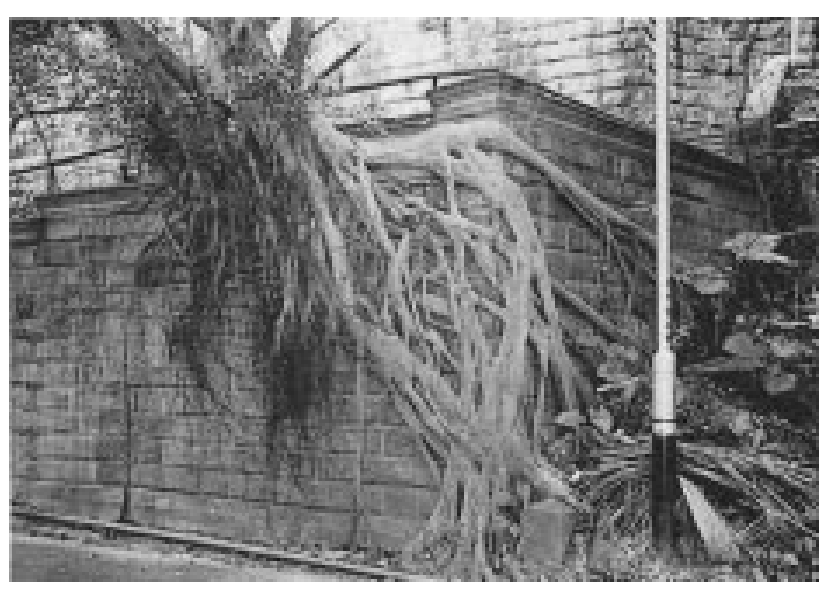

Figure6 Old stone walls in the sloping parts of urban $\mathrm{H}$ ong $\mathrm{K}$ ong permit spontaneous colonization by a host of plant life, including large trees such as this F icus microcarpa (Chinese Banyan) which sends out a profuse amount of roots gripping securely on the stone facade, furnishing a unique natural-cum-cultural heritage that deserves preservation.

stone retaining walls were used. T he oldest walls have open gaps between individual stones, furnishing ample opportunities for propagules to lodge, germinate and mature into plants of varying sizes and habits. Similar vertical or mural habitats accommodate mainly herbaceous vegetation in temperate latitudes (D arlington 1981; G ilbert 1992).

Stone walls in $\mathrm{H}$ ong $\mathrm{K}$ ong, with a humid-tropical environment, are colonized by a surprisingly diversified collection of flora with many woody components (J im 1996c). Some walls have abundant green cover, ranging from mosses, lichens and al gae to grasses, herbs, vines and ferns, and to shrubs and large trees (Fig. 6). T he largest organisms growing on stone walls are Ficus trees or Banyans ( $\mathrm{Jim}$ 1990b). Ficus microcarpa, $F$. virens and $F$. superba are common species which can attain $20 \mathrm{~m}$ tall with $1 \mathrm{~m}$ trunk diameter, including some champion specimens ( Jim 1994a). M asses of roots are sent out to grip the wall face and to penetrate crevices between stones and weep-holes, al lowing steadfast anchorage on an apparently precarious substratum. Direct typhoon attack with wind velocity exceeding $100 \mathrm{~km} / \mathrm{h}$ rarely dislodges them. They do not occupy significant ground space, and grow spontaneously with little human intervention or care. As many stone walls abut narrow roads in the hilly neighbourhoods, they present a special habitat with a rich complement of flora, adding significantly to the otherwise treeless streetscape.

Recent building redevelopment and road improvement, particularly the heightened concern about terrace wall stability (Geotechnical Control Office 1981), have brought large-scale wall demolition. Where reinforcement work was adopted in lieu of wholesale removal, the adding of a reinforced-concrete veneer often requires tree felling or causes severe damage to existing trees and other vegetation.

An ecologically-sound technique should be developed to salvage the genuinely unstable walls. Whenever feasible, natural regeneration should be allowed to run its own course. Overzealous tampering with old stone walls in the name of safety should be resisted. A register of stone walls of exceptionally high amenity value will help the protection cause (Jim 1996c). They should be subsumed under the A ntiquities and $\mathrm{M}$ onuments Ordinance as listed structures to be provided assured preservation for posterity. $\mathrm{N}$ ew stone walls can be designed by mimicking old ones with a view to enhancing spontaneous colonization by vegetation.

\section{Quality of arboricultural practice}

Inadequate, substandard or untimely tree-care erodes tree performance (Insley \& Buckley 1986) and increases management burden and cost. The close juxtaposition of trees and urban structures in $\mathrm{H}$ ong $\mathrm{K}$ ong makes tree care difficult (U rban et al. 1988). Research findings ( $\mathrm{im} 1986,1997 b)$ suggest a need to raise the standard of arboricultural practice. Arboricultural knowledge and skill are mastered mainly by government amenity officers trained overseas via diplomastandard dedicated courses; the technical staff and labourers are trained locally. The 'tree team' has the background to do routine tree-care jobs (Jim 1994c), but lacks a senior-grade officer with high-level training and experience. Creating an urban forester or municipal arboriculturist post as the repository of expertise knowledge will reinforce the treemanagement team.

F or research, local universities can team up with government departments to study urban-tree themes such as: (1) genetic make-up of the local tree population; (2) identification and development of superior cultivars (M oll 1987); (3) screening and introduction of good-quality species and varieties from other countries (Jim 1990c, d); (4) long-term trials in experimental arboretum; (5) improvement in nursery practice with a view to producing higher-quality planting materials; (6) development of local tree planting and maintenance standards; (7) diseases and pests of local trees and related issues on plant protection. T here is a need to raise an awareness that trees in human settlements, especially in densely-packed urban $\mathrm{H}$ ong $\mathrm{K}$ ong, require active maintenance. The widespread belief that trees will fare for themselves, and the inertia amongst people outside the government about caring for trees, can be dispelled through educational programmes.

\section{Conclusions}

D ue to geographical reality, the opportunity for tree growth in $\mathrm{H}$ ong $\mathrm{K}$ ong is inherently limited. The constraints are more akin to those of the developed rather than developing countries (Olembo \& de Rham 1987). T he fundamental scarcity of land for everything - buildings, roads, open space, greenery - has engendered an untypical built form where everything is telescoped together. It is as much a vertical city as a horizontal one in terms of space utilization. The community is conscious of the grave deficiency of developable land and the 
extremely expensive real estate. T he concept that urban land which is not built upon and used for roads is wasted is commonly held. The general attitude is to accord a low priority to amenity tree planting, being less so in public projects but strongly expressed in most private ones.

T he resulting exceedingly keen contest for space (U rban et al. 1988) engenders an oppressive growing environment, makes tree insertion in the compact urban matrix difficult, renders vigorous tree growth unlikely, and results in frequent tree damage. Such a bleak scenario is believed to have conditioned professionals and lay-persons subconsciously to accept less healthy trees and tree loss. This societal acceptance is not easy to reverse, but educational and publicity programmes can help to dissipate the misconceptions. Exemplary development projects illustrating the synergistic coexistence of trees and buildings should help to change attitudes towards an important urban infrastructure.

T he tree population which is disproportionately limited in relation to the human population should be increased, yet the tremendous pressure on existing trees is working against this objective. Additionally, pressure on the provision of potential space for amenity vegetation can trap people in a vicious circle as planting sites are usurped for other purportedly greater needs. T hus every tree and every plantable site is important, and they should not be given up or allowed to be degraded. $\mathrm{H}$ ong $\mathrm{K}$ ong should make the best use of the available habitats to aim at high-quality greenery. With a confined urban area and a phenomenal population density, the city does not require many trees to impose a significant impact on the cityscape. T he high-density development enhances not only the human dimension (Hughes 1996) but also the sylvan scale of the city. In other words, each tree can serve a large number of people, hence they are highly cost-effective, and it should not be difficult to justify planting more trees. The city's tree manager needs to have a comprehensive understanding of the negative as well as positive forces which mould the past, present and future structure of the urban forest. An optimal tree-cover configuration can be designed accordingly to maximize the functions and benefits of the urban forest (N owak 1993) in the local context.

As $\mathrm{H}$ ong $\mathrm{K}$ ong is striving to become an international city, it has to upgrade its environmental image. Other fast-growing cities are facing a similar situation. It will be paradoxical if a first-world economy is incongruously accompanied by a degraded third-world environment. Increasingly, the attractiveness of a city to residents, investors, business and related people from different lands will hinge upon the qual ity of the environment and the quality of human life. G reening the city on a moderate scale is an effective way to keep the place healthy, productive and competitive. It is very necessary to preserve and introduce more natural ingredients into the city (Cole 1986; H enke \& Sukopp 1986). T he multiple functions and values of urban trees can be objectively quantified and explained (M cPherson et al. 1997) to justify an adequate level of funding to sustain a long-term programme. A thorough overhaul of the current attitude and procedures for green space planning and management is earnestly needed.

\section{Acknowledgements}

The research grant support provided by the Environment and Conservation $F$ und and Woo Wheelock $G$ reen $F$ und is gratefully acknowledged. Deep appreciation is due for the help generously given by Alfred Cheung, Alan Cheung, L awrence Cheung, L. C. Choi, W. H. Leung, P. M ok and K. C. W ong of the U rban Services D epartment, M r. S. T . Chan of the Botany D epartment of the U niversity of $\mathrm{H}$ ong $\mathrm{K}$ ong, and G race Jim.

\section{References}

A ndresen, J.W . (1978) The greening of urban America. A merican F orests 84(1): $10-12,56-61$.

A rnold, C.L., Jr. \& G ibbons, C.J. (1996) Impervious surface coverage: the emergence of a key environmental indicator. J ournal of the A merican P lanning A ssociation 2): 243- 58.

Baines, C. (1994) T renching and street trees. A rboricultural J ournal 18. $231-6$.

Barker, P.A. (1994) Root barriers for controlling damage to sidewalks. In: The $L$ andscape B el ow G round, ed. G.W. W atson \& D. Neely, pp. 179-85. Savoy, Illinois: International Society of Arboriculture.

Barlett Tree Expert Company (1968) Street Tree Study for the District of C olumbia Final R eport. Stamford, Connecticut: 246 pp.

Batho, W.J.S. (1990) Review of Tree Preservation Policies and L egislation. Report to the Secretary of State for the Environment. $L$ ondon: D epartment of the Environment: $53 \mathrm{pp}$.

Bernatzky, A. (1978) T ree E cology and P reservation. Amsterdam: Elsevier: $357 \mathrm{pp}$

Bradshaw, A.D ., H unt, B. \& W almsley, T . (1995) T rees in the U rban $L$ andscape: Principles and Practice. L ondon: Spon: 272 pp.

B ristow, R. (1984) L and-use Planning in H ong K ong: H istory, P olicies and Procedures. H ong K ong: Oxford U niversity Press: 328 pp.

Bristow, R. (1989) H ong K ong's N ew T owns. Hong K ong: Oxford U niversity Press: 358 pp.

British Standards Institution (1991) G uide for T rees in R elation to Construction. BS 5837: 1991. L ondon: BSI: 24 pp.

Bullock, P. \& Gregory, P.J., eds. (1991) Soils in the U rban Environment. Oxford: Blackwell: $174 \mathrm{pp}$.

Census and Statistics D epartment (1997a) 1996 Population B y-census $\mathrm{M}$ ain R eport. H ong K ong: $\mathrm{H}$ ong $\mathrm{K}$ ong G overnment: 207 pp.

Census and Statistics D epartment (1997b) 1996 P opulation By-census $B$ asic Tables for District B oard D istricts. $\mathrm{H}$ ong $\mathrm{K}$ ong: $\mathrm{H}$ ong K ong G overnment: 87 pp.

Chaney, D.E., D rinkwater, L.E. \& Pettygrove, C.S. (1992) O rganic Soil A mendments and Fertilizers. Publication 21505. Oakland, California: Division of Agriculture and $\mathrm{N}$ atural Resources, U niversity of California: $36 \mathrm{pp}$.

Chevallerie, $\mathrm{H}$. de la (1986) The ecology and preservation of street trees. In: E cology and D esign in L andscape, ed. A.D. Bradshaw, D .A. G oode \& E.H.P. T horp, pp. 383-97. Oxford: Blackwell.

Cole, L . (1986) U rban opportunities for a more natural approach. In: E cology and Design in L andscape, ed. A.D. Bradshaw, D.A. Goode \& E.H.P. Thorp, pp. 417-31. Oxford: Blackwell. 
Coughlin, R.E., M endes, D.C. \& Strong, A.L. (1988) L ocal programs in the $U$ nited States for preventing the destruction of trees on private land. L andscape and U rban Planning 15 165- 71.

Craul, P.J. (1992) U rban Soil in L andscape D esign. N ew Y ork: J ohn W iley and Sons: $396 \mathrm{pp}$.

Cutler, D .F ., G asson, P.E \& \& F armer, M .C. (1990) T hewind blown tree survey: analysis of results. A rboricultural J ournal 14: 265-86.

Darlington, A. (1981) Ecology of Walls. L ondon: Heinemann: $138 \mathrm{pp}$

D orney, R.S., Evered, B. \& K itchen, C.M . (1986) Effects of tree conservation in the urban fringe of southern Ontario cities: 1970- 1984. U rban E cology 9 289-308.

Dudle, P. (1986) I mproving the living conditions for street trees in Zurich. A nthos 31 86: 28-30.

Evans, M .N , Bassuk, N . \& T rowbridge, P. (1990) Sidewalk design. $L$ andscape A rchitecture $\mathbf{8 0}(3):$ 102-3.

Gardening Which (1996) Our trees need help: an investigation into the effects of trenching on Britain's tree heritage following the introduction of the NJUG voluntary guidelines in April 1995. A rboricultural J ournal $\mathbf{2 0}$ 129-42.

Gasson, P.E. \& Cutler, D.F. (1990) Tree root plate morphology. A rboricultural J ournal 14: 193-264.

G eotechnical Control Office (1981) G eotechnical M anual for Slopes. H ong K ong: Public Works Department, H ong Kong G overnment: $228 \mathrm{pp}$.

Gilbert, 0. (1992) R ooted in Stone: The Natural Flora of U rban W alls. Peterborough, U K : English Nature: $32 \mathrm{pp}$.

Gilbertson, P. \& Bradshaw, A.D. (1985) T ree survival in cities: the extent and nature of the problem. Arboricultural J ournal 9 131- 42.

Gilman, E.F . (1988) T ree root spread in relation to branch dripline and harvestable root ball. $H$ ortS cience $\mathbf{2 3 ( 2 ) : ~ 3 5 1 - 3 . ~}$

Gilman, E.F. (1989) Predicting root spread from trunk diameter and branch spread. J ournal of A rboriculture 14(4): 85-9.

Gilman, E.F ., L eone, I.A. \& F lower, F.B. (1982) Influence of soil gas contamination on tree root growth. Plant and Soil $\mathbf{6 - 3}$ 3-10.

Goldsmith, F.B. (1988) Threats to woodlands in an urban landscape: a case study in Greater London. Landscape and U rban Planning 16 221-8.

G oldstein, J., Bassuk, N ., L indsay, P. \& U rban, J. (1991) From the ground down. L andscape A rchitecture 81(1): 66-8.

G rey, G.W. \& D eneke, F.J. (1986) U rban F orestry, 2nd edn. N ew Y ork: John Wiley and Sons: $299 \mathrm{pp}$.

H alverson, H.G \& \& H eisler, G.M . (1981) Soil temperatures under urban trees and asphalt. Research Paper NE-481. Broomall, Pennsylvania: U nited States D epartment of Agriculture F orest Service, N ortheastern F orest Experimental Station: $6 \mathrm{pp}$.

Harris, R.W. (1992) A rboriculture: I ntegrated M anagement of $L$ andscape Trees, Shrubs and V ines, 2nd edn. Englewood Cliffs, $\mathrm{N}$ ew J ersey: Regents/ Prentice H all: $674 \mathrm{pp}$.

Harris, R.W., Paul, J.L . \& L eiser, A.T . (1977) F ertilizing woody plants. L eaflet 2958. Berkeley, Cal ifornia: Cooperative Extension, Division of A gricultural Sciences, U niversity of California: $23 \mathrm{pp}$.

Henke, H. \& Sukopp, H. (1986) A natural approach in cities. In: $E$ cology and D esign in L andscape, ed. A.D. Bradshaw, D .A. G oode \& E.H.P. T horp, pp. 307-24. Oxford: Blackwell.

Hill, D.B. (1985) Forest fragmentation and its implications in Central $\mathrm{N}$ ew $\mathrm{Y}$ ork. F orest $\mathrm{E}$ cology and $\mathrm{M}$ anagement $\mathbf{2 2}$ 113- 28.

Holtam, B. (1980) Forestry in an urban environment. Quarterly J ournal of $F$ orestry 74: 141-52.

$\mathrm{H}$ ong K ong M useum of History (1982) The H ong K ong A lbum: A
Selection of the M useum's H istorical Photographs. Hong K ong: U rban Council: $99 \mathrm{pp}$.

Hughes, K J. (1996) Hong Kong: making the most of a compact city. U rban D esign I nternational 1(1): 95- 9.

Insley, H. \& Buckley, G .P. (1986) Causes and prevention of establishment failure in amenity trees. In: Ecology and Design in L andscape, ed. A.D. Bradshaw, D .A. G oode \& E.H .P. T horp, pp. 127-41. Oxford: Blackwell.

Izumi, S. (1983) The urban vegetation of T okyo and Sendai, J apan. In: M an's I mpact on V egetation, ed. W. H olzner, M .J.A. W erger \& I. I kusima, pp. 335- 40. T heH ague, T heN etherlands: D rW. Junk.

Jim, C.Y . (1986) U rban T ree Survey 1985: Pavement T rees M anaged by the $\mathrm{U}$ rban Council. H ong K ong: U rban Council: $84 \mathrm{pp}$.

Jim, C.Y . (1987a) The status and prospects of urban trees in $\mathrm{H}$ ong $K$ ong. L andscape and U rban Planning 14: 1-20.

$\mathrm{Jim}, \mathrm{C.Y}$. (1987b) L and use and amenity trees in urban $\mathrm{H}$ ong K ong $L$ and $U$ se Policy 4: 281-93.

Jim, C.Y . (1988) Preservation of a large Chinese Banyan on a construction site. J ournal of A rboriculture 14: 176- 80 .

Jim, C.Y. (1989a) The distribution and configuration of tree cover in urban $\mathrm{H}$ ong $\mathrm{K}$ ong. $\mathrm{G}$ eol ournal $\mathbf{1 8}$ 175-88.

Jim, C.Y. (1989b) T ree canopy cover, land use and planning implications in urban $\mathrm{H}$ ong $\mathrm{K}$ ong. $\mathrm{G}$ eoforum $\mathbf{2 0}$ 57-68.

Jim, C.Y . (1990a) T ree canopy characteristics and urban development in $\mathrm{H}$ ong $\mathrm{K}$ ong. $\mathrm{G}$ eographical Review 79. 210-25.

Jim, C.Y. (1990b) Trees in H ong K ong: Species for Landscape Planting. H ong K ong: H ong K ong U niversity Press: $434 \mathrm{pp}$.

Jim, C.Y. (1990c) Selection of tree species for urban plantings in tropical cities. In: Proceedings 19th World Congress of the International U nion of F orest R esearch O rganizations, August 1990. M ontreal: Division 1, Volume 1, pp. 236-47. M ontreal: International $U$ nion of $F$ orest Research Organizations.

Jim, C.Y. (1990d) Evaluation of tree species for amenity planting in H ong K ong. A rboricultural J ournal 14: 27-44.

Jim, C.Y. (1990e) Nature Interpretation in Lei Y ue M un Park $\mathrm{N}$ ative Woodland Trees. H ong Kong: Horticultural Section, U rban Council: $54 \mathrm{pp}$.

Jim, C.Y. (1991) Diversity of amenity species in Hong Kong. Quarterly J ournal of F orestry 55 233-43.

Jim, C.Y. (1992a) Provenance of amenity-tree species in Hong K ong. A rboricultural J ournal 16 11-23.

Jim, C.Y. (1992b) T ree-habitat relationships in urban $\mathrm{H}$ ong K ong Environmental Conservation 19. 209- 18

Jim, C.Y. (1993a) T rees and high-density urban development: opportunities out of constraints. $\mathrm{H}$ abitat I nternational 17. 1-17.

Jim, C.Y. (1993b) T rees and landscape of a suburban residential neighbourhood in $\mathrm{H}$ ong $\mathrm{K}$ ong. $\mathrm{L}$ andscape and $\mathrm{U}$ rban P lanning $\mathbf{2 3}$ $119-43$.

Jim, C.Y. (1993c) Soil compaction as a constraint to tree growth in tropical and subtropical urban habitats. Environmental Conservation $\mathbf{2 0}$ 35- 49.

Jim, C.Y. (1994a) Champion Trees in U rban Hong K ong. Hong K ong: U rban Council: $294 \mathrm{pp}$.

Jim, C.Y. (1994b) Evaluation and preservation of champion trees in urban $\mathrm{H}$ ong K ong. A rboricultural J ournal 18 25-51.

Jim, C.Y. (1994c) U rban T ree S urvey 1994 R oadside Trees M anaged by the $\mathrm{U}$ rban Council. H ong K ong: U rban Council: $470 \mathrm{pp}$.

Jim, C.Y. (1994d) U rban renewal and environmental planning in $\mathrm{H}$ ong K ong. The Environmentalist $\mathbf{1 4}$ 163-81.

Jim, C.Y . (1995) T ransplanting two champion specimens of mature Chinese Banyans. J ournal of A rboriculture $\mathbf{2 7}$ 289-95. 
Jim, C.Y. (1996a) Roadside trees in urban Hong Kong: Part I Census methodology. A rboricultural J ournal 20 221-37.

Jim, C.Y. (1996b) Roadside trees in urban Hong Kong: Part II Species composition. A rboricultural J ournal 20. 279-98.

Jim, C.Y . (1996c) Stone walls and their companion trees as a landscape element in urban $\mathrm{H}$ ong $\mathrm{K}$ ong. $Y$ uen $\mathrm{L}$ in ( $\mathrm{J}$ ournal of the $H$ ong $K$ ong Institute of $L$ andscape A rchitects) 96 36- 41.

J im, C.Y. (1997a) Roadside trees in urban H ong K ong: Part III T ree size and growth space. A rboricultural J ournal 21. 73-88.

Jim, C.Y . (1997b) Roadside trees in urban H ong K ong: Part IV T ree growth and environmental condition. A rboricultural J ournal $\mathbf{2 7}$. 89- 99.

Jim, C.Y . (1998a) Soil characteristics and management in an urban park in $\mathrm{H}$ ong $\mathrm{K}$ ong. Environmental $\mathrm{M}$ anagement $\mathbf{2}$ (in press).

J im, C.Y . (1998b) U rban soil characteristics and limitations for landscape planting in $\mathrm{H}$ ong $\mathrm{K}$ ong. $\mathrm{L}$ andscape and $\mathrm{U}$ rban Planning $\mathbf{3 9}$ (in press).

J ohnston, J. (1990) N ature A reas for C ity P eople. E cology H andbook 14. L ondon: L ondon E cology U nit: $116 \mathrm{pp}$.

KCR (1997) W est Rail. Hong Kong: Kowloon Canton Railway Corporation: $16 \mathrm{pp}$.

K elcey, J.G. (1978) T he green environment of inner urban areas. Environmental Conservation 5: 197- 203.

K opinga, J . (1994) A spects of damage to asphalt road pavings caused by tree roots. In: T he $L$ andscape B elow $G$ round, ed. G.W. W atson $\&$ D. N eely, pp. 165-78. Savoy, Illinois: International Society of Arboriculture.

L awrence, H.W . (1988) Origins of the tree-lined boulevard. The $\mathrm{G}$ eographical R eview 78 355- 74.

L o, C.P. (1992) H ong K ong. L ondon: Belhaven: 200 pp.

$M$ anning, O. (1979) Designing for nature in cities. In: N ature in Cities, ed. I.C. L aurie, pp. 3-36. Chichester: John W iley \& Sons.

M cPherson, E.G ., N owak, D., H eisler, G ., G rimmond, S., Souch, C., Grant, R. \& Rowntree, R. (1997) Quantifying urban forest structure, function, and value: the Chicago $U$ rban F orest Climate Project. U rban E cosystem 1(1): 49-61.

M essenger, S. (1986) Alkaline runoff, soil pH and white oak manganese deficiency. T ree $P$ hysiology 2 317- 25.

M iller, R.W . (1988) U rban F orestry: Planning and M anaging U rban $G$ reenspaces. Englewood Cliffs, $\mathrm{N}$ ew J ersey: Prentice $\mathrm{H}$ all: 404 pp.

M itchell, A.F., H allett, V.E. \& W hite, J.E.J . (1990) Champion T rees in the $B$ ritish I sles. F orestry Commission, Field Book 10. L ondon: H M SO : $33 \mathrm{pp}$.

M oll, G . (1987) Improving the health of the urban forest. A merican F orests $\mathbf{9 3}(11 / 12)$ : $61-4$.

M orell, J.D . (1992) Competition for space in the urban infrastructure. J ournal of A rboriculture 18(2): 73-5.

$\mathrm{N}$ ational J oint U tilities $\mathrm{G}$ roup (1995) G uidelines for planning, installation and maintenance of utility services in proximity to trees. Publication N umber 10. L ondon: NJU G : 23 pp.

N HBC (1992) N HBC Standards: building near trees. Amersham, Bucks, UK : N ational House Builders Corporation: 48 pp.

N owak, D.J. (1993) Historical vegetation change in Oakland and its implications for urban forest management. J ournal of A rboriculture 19(5): 313-19.

N owak, D.J. (1994) U nderstanding the structure of urban forests. J ournal of F orestry $\mathbf{9 2}(10)$ : 42- 6 .

Olembo, R.J . \& de R ham, P. (1987) U rban forestry in two different worlds. U nasylva 39. 26- 35.

Pearce, H . (1994) G rowing rootlessness. N ew Statesman and Society 7(312): $37-8$
Perry, T .0. (1982) T he ecology of tree roots and the practical significance thereof. In: U rban F orest Soils: A R eference W orkbook, ed. P.J. Craul, pp. 2.1-2.43. Syracuse, N ew Y ork: College of Environmental Science and Forestry, State U niversity of $\mathrm{N} \mathrm{ew}$ York.

Perry, T .O. (1994) Size, design and management of tree planting sites. In: The L andscape B elow G round, ed. G.W. W atson $\&$ D. N eely, pp. 3-15. Savoy, Illinois: International Society of Arboriculture.

Planning Department (1993) T erritorial Development Strategy Review Foundation Report. Hong Kong: Hong Kong G overnment: ix +92 pp.

Planning Department (1996) A nnual Report 1995. Hong Kong: $\mathrm{H}$ ong K ong G overnment: $49+$ xxiv pp.

Profous, G.V. \& L oeb, R.E. (1990) The legal protection of urban trees: a comparative world survey. J ournal of Environmental $L$ aw 2(2): 179-93.

Profous, G.V., R owntree, R.A.\& L oeb, R.E. (1988) T he urban forest landscape of Athens, G reece: aspects of structure, planning and management. A rboricultural J ournal 12 83-107.

Randall, C.E. \& Clepper, H. (1977) Famous and H istoric Trees. W ashington, District of Columbia: American Forestry Association: 90 pp.

Richards, N.A. \& Stevens, J.C. (1979) Streetside space and street trees in Syracuse - 1978. Syracuse, New York: College of Environmental Science and F orestry, State U niversity of $\mathrm{New}$ Y ork: $66 \mathrm{pp}$.

Sanders, R.A. (1984) Some determinants of urban forest structure. $\mathrm{U}$ rban E cology $813-27$.

Schmid, J.A. (1975) U rban V egetation: A R eview and C hicago Case S tudy. Research Paper N umber 161, D epartment of G eography, U niversity of Chicago, Chicago: $266 \mathrm{pp}$.

Scott, D ., Greenwood, R.D ., M offatt, J.D . \& T regay, R.J . (1986) W arrington N ew T own: an ecological approach to landscape design and management. In: E cology and D esign in L andscape, ed. A.D. Bradshaw, D.A. Goode \& E.H.P. Thorp, pp. 143-60. Oxford: Blackwell.

Shaw, K. (1977) Girdling roots. A rnoldia 37: 242- 7.

Shigo, A.L. (1989) A N ew Tree Biology, 2nd edn. Burham, N ew $\mathrm{H}$ ampshire: Shigo and T rees A ssociates: $618 \mathrm{pp}$.

T alarchek, C.M . (1990) The urban forest of N ew Orleans: exploratory analysis of relationships. U rban Geography $\mathbf{1 1}(1)$ : 65- 86.

T hrower, S.L. (1975) T he flora of H ong K ong in its geographical context. In: The V egetation of $\mathrm{H}$ ong $K$ ong, ed. L .B. Thrower, pp. 5- 19. H ong K ong: Royal A siatic Society.

T regay, R. (1979) U rban woodlands. In: N ature in C ities, ed. I.C. L aurie, pp. 267-95. Chichester: John W iley \& Sons.

T regear, T .R . \& Berry, L . (1959) The D evelopment of H ong K ong as T old in $M$ aps. $H$ ong $K$ ong: $H$ ong $K$ ong $U$ niversity Press: 31 pp.

U rban, J., Sievert, R. \& Patterson, J. (1988) T rees and space: a blueprint for tomorrow. A merican F orests 94 (7/ 8): 58- 74 .

W are, G. (1990) Constraints to tree growth imposed by urban soil alkalinity. J ournal of A rboriculture $\mathbf{1 6}$ 35- 8 .

Warner, J. (1979) F ragrant $\mathrm{H}$ arbour: $\mathrm{E}$ arly $\mathrm{P}$ hotographs of $\mathrm{H}$ ong K ong, 3rd edn. H ong K ong: John W arner: 192 pp.

Watson, G.W., Clark, S. \& Johnson, K. (1990) Formation of girdling roots. J ournal of A rboriculture 168): 197-202.

W atson, G.W., K elsey, P. \& W oodtli, K . (1996) Replacing soil in the root zone of mature trees for better growth. J ournal of A rboriculture 22(4): 167-73. 
W atson, G .W . \& N eely, D ., eds. (1994) T heL andscape B elow G round. Savoy, Illinois: International Society of A rboriculture: 222 pp.

Whitlow, T .H ., Bassuk, N . \& Reichert, D . (1992) A 3-year study of water relations of urban street trees. J ournal of A pplied E cology $\mathbf{2}$. 436- 50.
Wong, Y.C.R., Chau, K.W. \& Lai, L.W.C. (1996) Prices and Competition in Property $M$ arkets: A nalysis and Policy I ssues. $\mathrm{H}$ ong $\mathrm{K}$ ong: $\mathrm{H}$ ong $\mathrm{K}$ ong $\mathrm{C}$ entre for E conomic Research, U niversity of Hong K ong: 156 pp. 